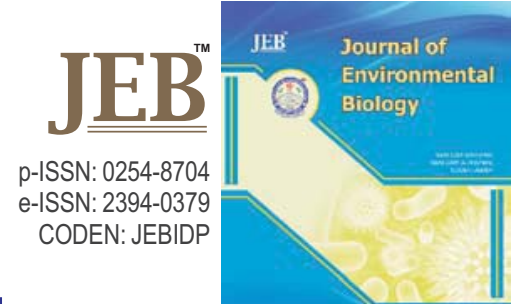

\title{
Effects of electromagnetic radiations on diversity and breeding biology of birds living near power lines and mobile towers at Ludhiana, Punjab
}

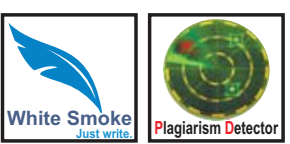

Authors Info

T.K. Kler*, M. Kumar and N. Vashishat

Department of Zoology, Punjab Agricultural University, Ludhiana-141 004, India

*Corresponding Author Email : tejdeepkler@pau.edu

Key words

Avifaunal diversity

Breeding biology

Community structure

Electromagnetic radiations

Mobile towers

\section{Publication Info}

Paper received : 09.03.2016

Revised received : 17.08 .2016

Re-revised received : 23.03 .2017

Accepted:01.07.2017

\section{Abstract}

Aim : Mobile towers and high voltage power transmission towers are ubiquitous in the developed world and in urban areas of many developing countries. The present study was undertaken to monitor relative abundance of avian species in relation to mobile towers and high voltage power transmission towers.

Methodology : Point count method was used for the survey. The observations were recorded from January to December 2014 at selected eleven sites i.e., five in relation to mobile towers; five with respect to high voltage power transmission towers and one control site, respectively, at the campus of Punjab Agricultural University (PAU), Ludhiana.

Results : Species richness of 20,27 and 36 bird species were observed at the selected sites near mobile towers, near high voltage power transmission towers and control site, respectively. The breeding success of Common Myna was $88.11 \%$ in the artificial nests installed near mobile towers. Breeding success of $96.25 \%$ and $83.33 \%$ was recorded by Common Myna and Spotted Owlet in the artificial nests installed near high voltage power transmission towers. The breeding success of Common Myna and Spotted Owlet was $100.0 \%$ and $87.5 \%$ in artificial nests installed at control site.

Interpretation : Preliminary findings of this study revealed that there was low bird abundance and breeding success near mobile towers and high voltage power transmission towers as compared to control site. It may be possible due to the clandestine effect of electromagnetic radiations along with the other unforeseen factors.

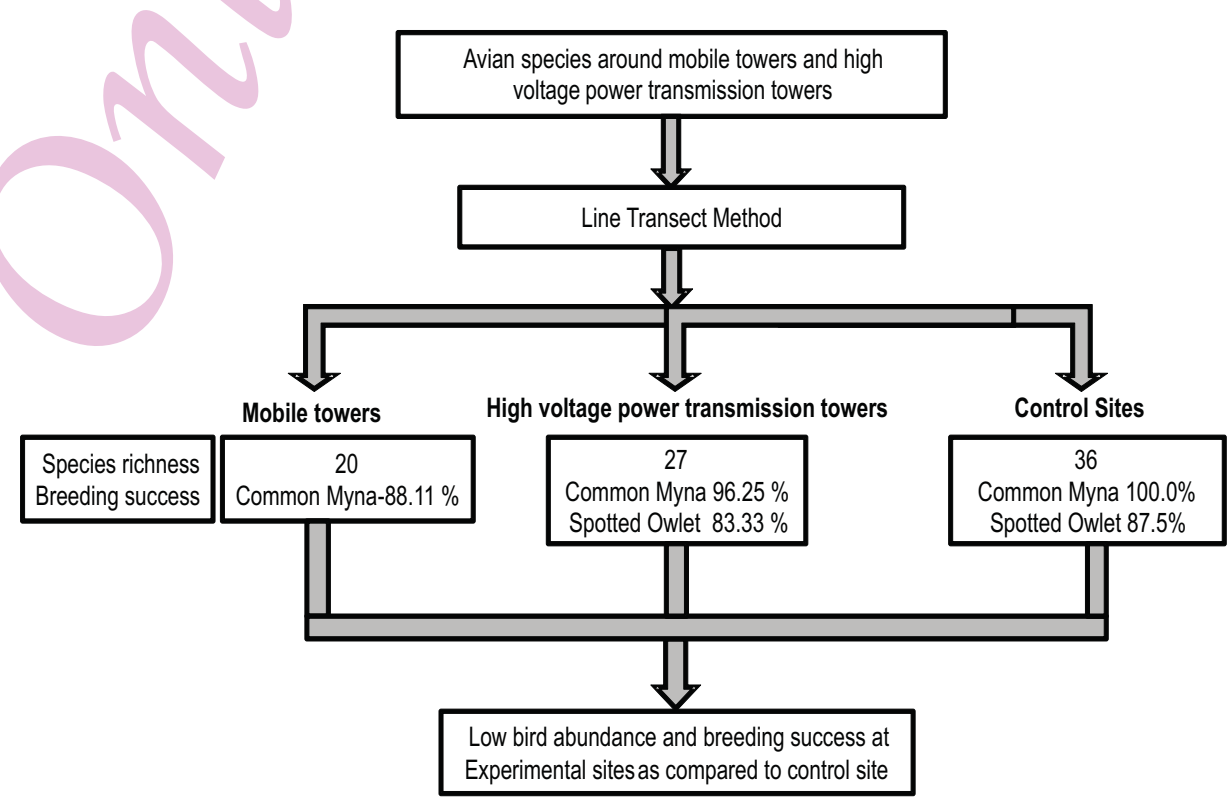




\section{Introduction}

Rapid development of telecommunication devices in last decade has caused enhancement of human interference with nature. Similar to every device that carries an electric current, power lines and cell tower antenna emit electric and magnetic fields that are collectively called electromagnetic fields (EMFs). Before the 1990's, electromagnetic radiations were emitted from few radio and television transmitters located in remote areas and/or high elevations. Since then, mobile base stations masts have been spreading across urban centres and have increased electromagnetic pollution (Balmori and Hallberg, 2007). According to Kumar (2010), cell tower antennas transmit in the frequency range of $869-894 \mathrm{MHz}$ (CDMA), 935-960 MHz (GSM900) and 1810-1880 MHz from (GSM1800). A continuous chronic exposure to a wide range of modulated radio frequency electromagnetic fields burdens all species and groups including humans across the globe (Yadav and Sharma, 2008). The strength of electromagnetic fields depends upon the current intensity carried through a conductor and the distance of exposure from the source (Fernie et al., 2000). Both fields are highest immediately around a power line and diminish rapidly with distance away from the source (Fernie and Reynolds, 2005). The unseen electromagnetic radiation emitted from mobile towers, transmission lines and power lines induces undesirable impact on living beings in a multiple ways (Fernie et al., 2000; Fernie and Reynolds, 2005; Everaert and Bauwens, 2007; Bhattacharya and Roy, 2013).

Birds have been widely used to analyze the environmental significance of exposure to non ionizing radiation. The ability of birds to detect electromagnetic stimuli has been documented by several studies (Thalau et al., 2005; Cucurachi et al., 2013). The electric power lines and mobile towers are beneficial to birds as they provide additional sites for perching, roosting, hunting and nesting. Consequently, birds are exposed for longer duration to EMF generated by these sources (Fernie et al., 2000). There are numerous examples of the detrimental effects of power lines in terms of birds that die through collision or electrocution (Fernie and Reynolds, 2005). Since birds are environmental indicator of ecosystem health because of their thin skull, feathers as dielectric receptor, high mobility and use of areas having high electromagnetic field (Fernie et al., 2000; Bhattacharya and Roy, 2013), field studies of avifauna can reveal possible effects of long-term exposure to radiation from mobile towers and high voltage power transmission towers. The present study was carried out with an objective to investigate the effects of electromagnetic radiations on diversity and breeding success of birds that live intimately with power lines and mobile towers.

\section{Materials and Methods}

The observations were recorded at selected eleven sites i.e., five sites each within $100 \mathrm{~m}$ radius of mobile towers and high voltage power transmission towers and one control site (having similar habitat and a minimum distance of $500 \mathrm{~m}$ from the mobile towers and high voltage power transmission towers) to monitor avian diversity in the campus of Punjab Agricultural University, Ludhiana. The point count method was followed for the survey (Javed and Kaul, 2002) and observations were taken twice a week. All birds sighted or heard, perching on towers, including those in flight in transect area were counted for record. The birds in study area were observed with naked eye or through Bushnell Binocular (8X42) from a long distance in order to avoid interference and identification were based on keys (Ali, 2002). Standardized common and scientific names of birds were described as per Manakadan and Pittie (2001). Total number of bird species and their relative abundance were estimated. Relative abundance $(\%)$ was calculated as: (ni/N) x 100 , where ni is the number of birds of $i^{\text {th }}$ species and $\mathrm{N}$ is the total number of birds of all species. To record breeding success, artificial nests @ five/site were installed within $50 \mathrm{~m}$ radius of mobile towers and high voltage power transmission towers at selected sites. Breeding success was calculated by recording the successful hatching (\% age) of egg laid in the artificial nest. Artificial nests were also installed at selected control site.

\section{Results and Discussion}

Species richness of 20 and 27 bird species were observed at the selected sites near mobile towers and high voltage power transmission towers as compared to 36 bird species at control site, including common species recorded at all locations (Table 1, 2, 3). The most abundant bird species near mobile towers was Common Pariah Kite, where as House Crow was found abundant near high voltage power transmission towers and Common Myna was most abundant bird species at control site (Table 1, 2, 3). Common Myna was found to occupy artificial nests installed near mobile towers, high voltage power transmission towers and at control sites, while Spotted Owlet occupied the artificial nests installed near high voltage power transmission towers and at control sites only (Table 4).

Common Myna was observed to breed in eight artificial nests out of total 25 artificial nests installed at sites near mobile towers. The occupation rate of artificial nests by Common Myna was $32 \%$ near mobile towers with $92.5 \%$ overall breeding success in occupied artificial nests. Individual site specific breeding success of Common Myna ranged from 55.55\% - 100.0 $\%$ at the selected sites (Table 3). Repeat egg laying was recorded in all the artificial nests occupied by Common Myna near mobile towers (Table 4). Breeding of Common Myna was observed in eleven artificial nests out of total twenty five artificial nests installed at five selected sites near high voltage power transmission towers. The occupation rate of artificial nests by Common Myna was 44\% near high voltage power transmission towers. The overall breeding success of Common Myna was $96.25 \%$ in artificial nests. Individual site specific breeding success of Common Myna in artificial nests ranged from $81.25 \%$ to $100.0 \%$ at five selected sites (Table 4). There was noted repeat egg laying in the occupied artificial nests by Common Myna at one site. The breeding success of Spotted Owlet was $81.25 \%$ in 
Table 1 : Relative abundance of different bird species near mobile towers at selected five locations, PAU, Ludhiana, Punjab

\begin{tabular}{|c|c|c|c|c|c|c|c|c|c|c|}
\hline \multirow[t]{2}{*}{ Bird species } & \multicolumn{2}{|l|}{ Site I } & \multicolumn{2}{|l|}{ Site II } & \multicolumn{2}{|l|}{ Site III } & \multicolumn{2}{|l|}{ Site IV } & \multicolumn{2}{|l|}{ Site V } \\
\hline & Tower & $\begin{array}{l}\text { Surrou- } \\
\text { ndings }\end{array}$ & Tower & $\begin{array}{l}\text { Surro- } \\
\text { undings }\end{array}$ & Tower & $\begin{array}{l}\text { Surro- } \\
\text { undings }\end{array}$ & Tower & $\begin{array}{l}\text { Surro- } \\
\text { undings }\end{array}$ & Tower & $\begin{array}{l}\text { Surro- } \\
\text { undings }\end{array}$ \\
\hline Black Drongo (Dicrurus macrocercus) & - & - & - & - & - & - & - & - & - & 6.25 \\
\hline Blue Rock Pigeon (Columba livia) & - & 2.63 & - & 30 & - & 23.08 & - & - & - & - \\
\hline Cattle egret (Bubulcus ibis) & - & - & - & - & - & 7.69 & - & - & - & 6.25 \\
\hline Common babbler (Turdoides caudata) & - & 31.58 & - & - & - & - & - & 11.57 & - & 18.75 \\
\hline $\begin{array}{l}\text { Common Golden backed woodpecker } \\
\text { (Dinopium javanense) }\end{array}$ & - & 2.63 & - & - & - & & - & - & - & - \\
\hline Common Hoopoe (Upupa epops) & - & - & - & - & - & - & - & - & - & 6.25 \\
\hline Common Myna (Acridotheres tristis) & - & 26.32 & - & 25 & - & 26.92 & - & 24.79 & 50.0 & 18.75 \\
\hline Common Pariah Kite (Milvus migrans) & 75.0 & 13.16 & - & - & 75.0 & 11.54 & 100.0 & 34.71 & 50.0 & 6.25 \\
\hline Common peafowl (Pavo cristatus) & - & - & - & - & 25.0 & & - & 12.4 & - & - \\
\hline $\begin{array}{l}\text { Eurasian Collared-Dove } \\
\text { (Streptopelia decaocto) }\end{array}$ & - & - & - & - & & - & - & - & - & 12.5 \\
\hline House Crow (Corvus splendens) & 25.0 & 18.42 & - & 20 & & & - & 9.92 & - & 12.5 \\
\hline Indian Pond-Heron (Ardeola grayii) & - & - & - & & - & 7.69 & - & - & - & - \\
\hline Jungle Babbler (Turdoides striatus) & - & - & - & 10 & - & - & - & - & - & - \\
\hline Lesser Coucal (Centropus bengalensis) & - & 2.63 & - & - & - & - & - & - & - & - \\
\hline Purple Sunbird (Nectarinia asiatica) & - & - & - & & - & - & - & - & - & 12.5 \\
\hline Red-vented Bulbul (Pycnonotus cafer) & - & 2.63 & - & & - & - & - & - & - & - \\
\hline $\begin{array}{l}\text { Red-wattled Lapwing } \\
\text { (Vanellus indicus) }\end{array}$ & - & - & - & 10 & - & - & - & 1.65 & - & - \\
\hline $\begin{array}{l}\text { Rose-ringed Parakeet } \\
\text { (Psittacula krameri) }\end{array}$ & - & - & - & 5 & - & 11.54 & - & 3.31 & - & - \\
\hline Spotted Munia (Lonchura punctulata) & - & - & - & - & - & 11.54 & - & - & - & - \\
\hline $\begin{array}{l}\text { Yellow-legged Green-Pigeon } \\
\text { (Treron phoenicoptera) }\end{array}$ & - & - & & & - & - & - & 1.65 & - & - \\
\hline
\end{tabular}

occupied artificial nests installed near high voltage power transmission towers. The breeding success of Common Myna and Spotted Owlet was $100.0 \%$ and $87.5 \%$ in artificial nests installed at control site (Table 4).

More species richness at control site as compared to site near mobile towers and high voltage power transmission towers may be due to the preference of control sites by the bird species. Similar findings have earlier been reported by Everaert and Bauwens, 2007; Balmori, 2005. It was reported that microwaves (1 $\mathrm{MHz}$ to $3 \mathrm{GHz}$ ) may affect the productivity of White Stork, Ciconia ciconia (Balmori, 2005). Many workers have reported decrease in bird species richness in urban areas having high level of electromagnetic radiation, which is correlated with the increasing number of cell towers (Rajashekar and Venkatesha 2008, 2011, 2015; Shaw et al., 2008; Khera et al., 2010; Bhattacharya et al., 2011). In the present study less species richness was found within $100 \mathrm{~m}$ radius of mobile towers and high voltage power transmission towers. Bird species diversity decreased due to transmission line corridors, sparrows were observed to avoid transmission lines (Balmori and Hallberg, 2007). Disappearance of sparrows from urban areas and installation of GSM towers (GSM $900 \mathrm{MHz}$ and DCS $1800 \mathrm{MHz}$ ) are interrelated, and electromagnetic pollution either by itself or in combination with other factors is responsible for decline of common birds like House Sparrow (Balmori and Hallberg, 2007).

In the present study, the breeding success of Common Myna and Spotted Owlet was recorded to be more in the artificial nests installed at control site as compared to experimental sites, which might be due to the clandestine effect of electromagnetic radiations along with the other unforeseen factors. Though electromagnetic field is transient in nature, but it may induce serious hazards during breeding season due to long term exposure. Similar findings were also recorded by other workers, where abundance and breeding success was more at control site as compared to experimental sites (Peach et al., 2008; Balmori, 2009; Anders et al., 2011; Kaur et al., 2016). A few number of natural nests of local birds have been found near the vicinity of mobile tower (Dongre and Verma, 2009; Kaur et al., 2016). Exposure to electromagnetic radiation affects nest building, egg fertility, clutch size, hatching and survival of chicks (Balmori, 2009). Different studies have concluded that the mobile towers emit electromagnetic radiations (frequency of $900-1800 \mathrm{MHz}$ ) which affect the nervous system, navigational skills, foraging ability and breeding success of bird species 


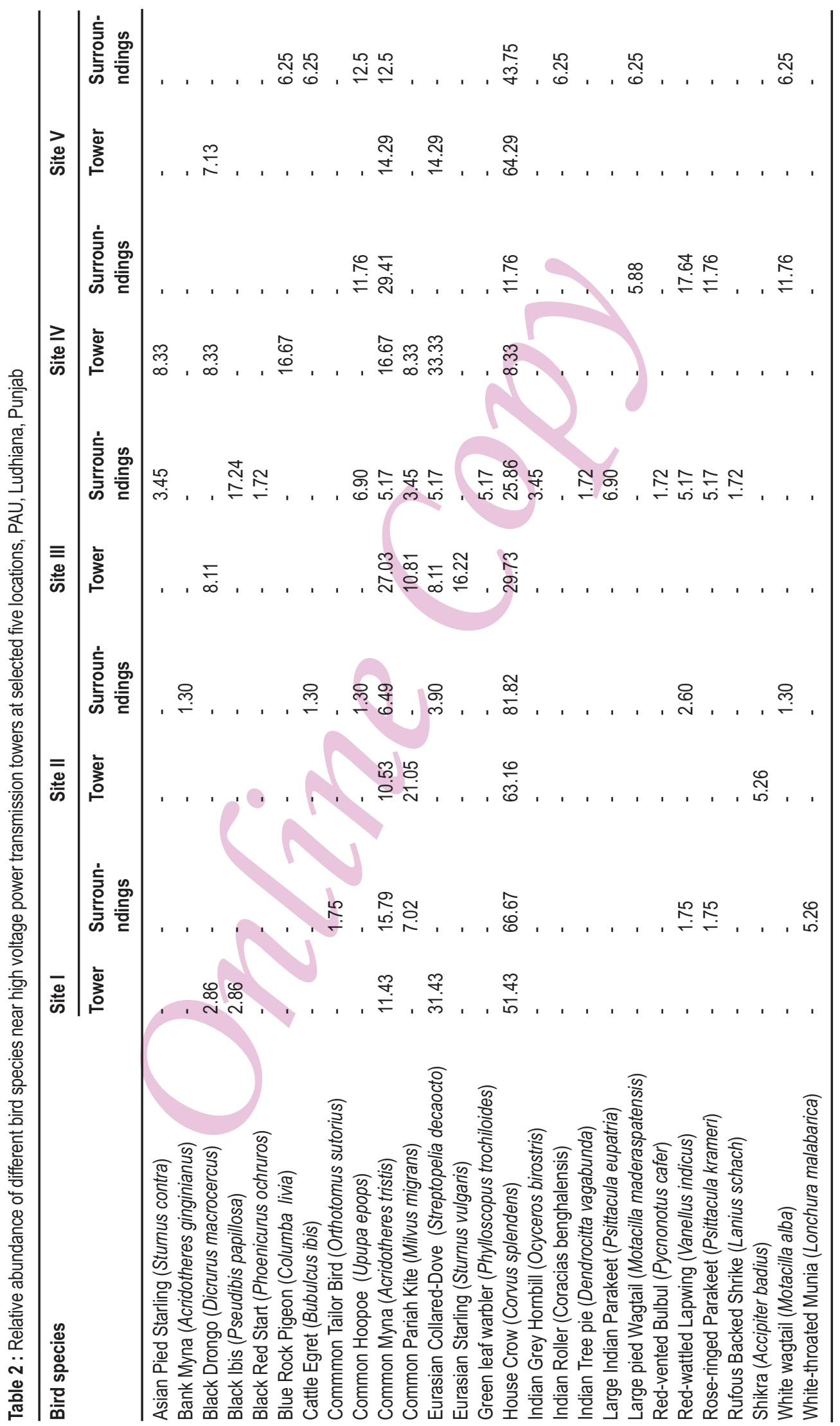


Table 3 : Relative abundence of different bird species at selected control site, PAU, Ludhiana, Punjab

\begin{tabular}{|c|c|c|c|}
\hline Bird species & $\begin{array}{l}\text { Relative } \\
\text { abundance }\end{array}$ & Bird species & $\begin{array}{l}\text { Relative } \\
\text { abundance }\end{array}$ \\
\hline Ashy Prinia (Prinia socialis) & 0.63 & Greenish Leaf Warbler (Phylloscopus trochiloides) & 1.90 \\
\hline Asian Koel (Eudynamys scolopacea) & 0.63 & Grey Francolin (Francolinus pondicerianus) & 1.90 \\
\hline Asian Pied Starling (Sturnus contra) & 1.27 & House Crow (Corvus splendens) & 12.66 \\
\hline Bank Myna (Acridotheres ginginianus) & 6.33 & Indian Hoopoe (Upupa epops) & 0.63 \\
\hline Black Drongo (Dicrurus macrocercus) & 1.90 & Indian Pond Heron (Ardeola grayii) & 1.90 \\
\hline Black Francolin (Francolinus francolinus) & 0.63 & Indian Roller (Coracias benghalensis) & 1.27 \\
\hline Black Ibis (Pseudibis papillosa) & 1.27 & Lesser Coucal (Centropus bengalensis) & 1.90 \\
\hline Black Redstart (Phoenicurus ochruros) & 0.63 & Little Brown Dove (Streptopelia senegalensis) & 1.27 \\
\hline Black-winged Stilt (Himantopus himantopus) & 2.53 & Oriental Magpie-Robin (Copsychus saularis) & 0.63 \\
\hline Blue Rock Pigeon (Columba livia) & 4.43 & Paddy Field Pipit (Anthus rufulus) & 4.43 \\
\hline Brown-headed Barbet (Megalaima zeylanica) & 0.63 & Pied Bushchat (Saxicola caprata) & 1.27 \\
\hline Cattle Egret (Bubulcus ibis) & 3.16 & Red-vented Bulbul (Pycnonotus cafer) & 2.53 \\
\hline Common babbler (Turdoides caudata) & 2.53 & Red-wattled Lapwing (Vanellus indicus) & 6.33 \\
\hline Common Myna (Acridotheres tristis) & 15.19 & Rose-ringed Parakeet (Psittacula krameri) & 5.06 \\
\hline Common Pariah Kite (Milvus migrans) & 0.63 & Shikra (Accipiter badius) & 0.63 \\
\hline Common Swallow (Hirundo rustica) & 3.16 & Spotted Munia (Lonchura punctulata) & 2.53 \\
\hline Eurasian Collared-Dove (Streptopelia decaocto) & 3.16 & White-breasted Kingfisher (Halcyon smyrnensis) & 1.27 \\
\hline Green Bee-eater (Merops orientalis) & 1.90 & Wire-tailed Swallow (Hirundo smithii) & 1.27 \\
\hline
\end{tabular}

Table 4 : Data recorded on different parameters of breeding ecology of birds utilizing artificial nests, PAU, Ludhiana, Punjab

\begin{tabular}{|c|c|c|c|c|c|c|}
\hline Locations & $\begin{array}{l}\text { Occupation of artificial nest } \\
(\%) \text { by Common Myna }\end{array}$ & No of clutches & $\begin{array}{l}\text { Total eggs } \\
\text { laid }\end{array}$ & $\begin{array}{l}\text { Predation of } \\
\text { eggs (\%) }\end{array}$ & $\begin{array}{l}\text { Total egg } \\
\text { hatched }\end{array}$ & $\begin{array}{l}\text { Breeding } \\
\text { success (\%) }\end{array}$ \\
\hline \multicolumn{7}{|c|}{ Mobile tower } \\
\hline Site I & 40.0 & 5 & 21 & 0.0 & 21 & 100.0 \\
\hline Site II & 40.0 & 5 & 23 & 0.0 & 23 & 100.0 \\
\hline Site III & 40.0 & 3 & 15 & 6.67 & 14 & 93.33 \\
\hline Site IV & 20.0 & 2 & 9 & 44.44 & 5 & 55.55 \\
\hline Site V & 20.0 & 3 & 12 & 8.33 & 11 & 91.67 \\
\hline \multicolumn{7}{|c|}{ High voltage power transmission towers } \\
\hline Site I & 60.0 & 3 & 13 & 0.0 & 13 & 100.0 \\
\hline \multirow[t]{2}{*}{ Site II } & 60.0 & 4 & 19 & 0.0 & 19 & 100.0 \\
\hline & $40.0^{*}$ & 2 & 6 & 16.67 & 5 & 83.33 \\
\hline Site III & 20.0 & 1 & 4 & 0.0 & 4 & 100.0 \\
\hline Site IV & 60.0 & 3 & 16 & 18.75 & 13 & 81.25 \\
\hline Site V & 20.0 & 1 & 4 & 0.0 & 4 & 100.0 \\
\hline \multirow[t]{2}{*}{ Control } & 66.66 & 14 & 61 & 0.0 & 61 & 100.0 \\
\hline & $20.0^{*}$ & 2 & 8 & 12.5 & 7 & 87.5 \\
\hline
\end{tabular}

${ }^{*}$ Artificial nest occupied by Spotted Owlet

(Peach et al., 2008; Anders et al., 2011). Long term exposure to higher levels of radiations has been recorded to negatively affect the abundance or behaviour of House Sparrow in the wild (Everaert et al., 2007; Pradha, 2015). It may be concluded from the present study that radiations interfere with the reproduction of avian species and to some degree adversely effect incubation during breeding season, as reflected by high breeding success in control site than the sites located near mobile tower and high voltage power transmission towers.

\section{Acknowledgments}

Authors are grateful to Indian Council of Agricultural Research, New Delhi for financial support and to the Head, 
Department of Zoology, Punjab Agricultural University, Ludhiana for providing necessary facilities. Authors are also thankful to Mr. Harpal Singh Thandi for his technical help during the surveys.

\section{References}

Ali, S.: The Book of Indian Birds. $13^{\text {th }}$ Edn., Bombay Natural History Society, Oxford University Press Inc. Bombay (2002).

Anders, P., B. Andea and G. Rudolfsen: Chernobyl birds have smaller brains. PLoS ONE, 6, e16862 (2011).

Balmori, A.: Electromagnetic pollution from phone masts. Effect on wildlife. Pathophysiology, 16,191-199 (2009).

Balmori, A.: Possible effects of electromagnetic fields from phone masts on a population of White Stork (Ciconia ciconia). Electromagn. Biol. Med., 24, 109-119 (2005).

Balmori, A. and O. Hallberg: The urban decline of the House Sparrow (Passer domesticus) : A possible link with electromagnetic radiation. Electromagn. Biol. Med., 26, 141-151(2007).

Bhattacharya, R., R. Roy and C. Goswami: Studies on the response of house sparrows to artificial nest. Int. J. Env. Sc., 1, 1574-1581 (2011).

Bhattacharya, R. and R. Roy: Impacts of communication towers on Avians:AReview. Int. J. Elect. Comm. Tech., 4, 137-139 (2013).

Cucurachi, S., W. L. M. Tamis, M. G. Vijver, W. J. G. M. Peijnenburg, J. F. B. Bolte and G. R. de Snoo: A review of the ecological effects of radiofrequency electromagnetic fields (RF-EMF). Env. Int., 51, 116-140 (2013).

Dongre, S. D. and R. G. Verma : Effect of cell phone radiation on Gauriya sparrow Passer domesticus. Int. Res. J., 2, 51-52. (2009).

Everaert, J. and D. Bauwens: A possible effect of electromagnetic radiation from mobile phone base stations on the number of breeding house sparrows (Passer domesticus). Elect. Bio. Medi., 26, 63-72(2007).

Fernie, K. J. and S. J. Reynolds : The effects of electromagnetic fields from power lines on avian reproductive biology and physiology : A Review. J. Toxic. Env. Hlth., 8, 127-140 (2005).

Fernie, K. J., D. M. Bird, R. D. Dawson and P. C. Lague: Effects of electromagnetic fields on the reproductive success of American Kestrels. Physio. Biochem. Zoo., 73, 60-65 (2000).
Javed, S. and R. Kaul: Field Methods for Bird Surveys. Bombay Natural History Society, Department of Wildlife Sciences, Aligarh Muslim University, Aligarh and World Pheasant Association, South Asia Regional Office (SARO), New Delhi, India (2002).

Kaur, J., T. K. Kler, J. S. Kang and M. Kumar: Avian diversity in relation to cell phone tower in agricultural crop fields of Ludhiana, Punjab, India. Int. JAdv. Res., 4, 492-502 (2016).

Khera, N., A. Das, S. Srivastava and S. Jain: Habitat-wise distribution of the House Sparrow (Passer domesticus) in Delhi, India. Urban Eco., 13,147-154 (2010).

Kumar, G.: Report on cell tower radiation. IIT, Mumbai, pp. 1-31 (2010).

Manakadan, R. and A. Pittie : Standardized common and scientific names of the birds of the Indian subcontinent. Buceros., 6, 1-38 (2001).

Pradha, L.: Impact of electromagnetic radiations on house sparrow (Passerdomesticus). Int. J. Engi. Res. Tech., 4, 1-11 (2008).

Peach, W., K. Vincent and J. Fowler: Reproductive success of house sparrows along an urban gradient. Animal Conversation, 11, 1-11 (2008).

Rajashekar, S. and M. G. Venkatesha : Occurrence of house sparrow Passer domesticus indicus in and around Bangalore. Curr. Sci., 94, 446-449. (2008).

Rajashekra, S. and M.G. Venkatesha: Community composition of aquatic birds in lakes of Bangalore, India. J. Env. Bio., 32, 77-83 (2011).

Rajashekra, S. and M.G. Venkatesha: Temporal and spatial avian community composition in urban landscapes of the Bangaluru region, India. J. Env. Bio., 36, 607-616 (2015).

Shaw, L. M., D. Chamberlain and M. Evans : The house sparrow Passer domesticus in urban areas : Reviewing a possible link between post decline distribution and human socioeconomic status. J. Orinthol., 149, 293-299 (2008)

Thalau, P., T. Ritz, K. Stapput, R. Wiltschko and W. Wiltschko: Magnetic compass orientation of migratory birds in the presence of a 1.315 MHz oscillating field. Naturwissenschaften, 92, 86-90 (2005).

Yadav, A. S. and M. K. Sharma: Increased frequency of micronucleated exfoliated cells among humans exposed in vivo to mobile telephone radiations. Mutat. Res., 650, 175-180 (2008). 